\title{
Incidence of Endoparasites in Captive Pheasants in Arignar Anna Zoological Park, Vandalur, Chennai, India
}

\author{
R. Pradeep*, A. Senthilkumar, A. Sangaran, S. Prathaban and A. Pradeep
}

81/4 East Street, Pandavarmangalam, Kovilpatti, Thoothukudi-628502, Tamil Nadu, India

*Corresponding author

\begin{tabular}{l} 
K e y w o r d s \\
Captive pheasants, \\
Zoological park, \\
Chennai. \\
Article Info \\
$\begin{array}{l}\text { Accepted: } \\
\text { 26 July } 2017 \\
\text { Available Online: } \\
\text { 10 September } 2017\end{array}$ \\
\hline
\end{tabular}

\section{Introduction}

Pheasants belong to the family 'Phasianidae' and Order 'Galliformes'. Pheasants are brightly coloured, large bodied and ground dwelling birds. These birds exhibit greater sexual dimorphism in both size and plumage. Galliformes comprises of 70 genera and 284 species, while 45 species are known from India. The natural range of the pheasants spreads throughout South-east Asia.

These species inhabit wide range of habitats such as lowland tropical rainforest (e.g. Crested fireback - Lophura ignita, Congo peafowl - Afropavo congensis), montane tropical forest (e.g. Mountain peacock pheasant - Polyplectronino pinatum), temperate coniferous forest (e.g. Western tragopan - Tragopan melanocephalus ), subalpine scrub (e.g. Blood pheasantIthaginis cruentus), alpine meadows (e.g. Chinese monal - Lophopho ruslhuysii), tropical dry-deciduous forests (e.g. Grey jungle fowl - Gallus sonneratii) and agricultural lands (e.g. Indian peafowl Pavocristatus).

In captivity, peafowl can live for about 23 years but it is estimated that they live only for about 15 years in the wild Flower, (1938). Domesticated peacocks and other fancy birds develop a variety of infections due to unnatural habitat and suboptimal management 
conditions Athar et al., (2001). Regrettably, like other captive birds, they are also suffering from potential stress and frequent cases of parasitic infections, which are among the most prevailing diseases that affect them El-shahawy, (2010). The major stress factor that can lead to lowered performance and malnutrition is intestinal parasitism Badran and Lukesova, (2006). Parasitic infections are among the most common sanitary problems affecting wild birds and become either a sub clinical condition or even a cause of death, they have attention only when they have threatened agriculture or human health

Pheasants, also being insectivorous, tend to scavenge on worms of decaying animals and often introduced to endoparasitic infections. Pheasants were susceptible to a wide range of diseases, in which parasitism is one of the major health problem, which might be transmitted from one group of birds to other. This study helps in identification of this parasitic prevalence in captive conditions.

\section{Materials and Methods}

A total of 76 samples from droppings (fecal samples) were collected from a variety of pheasants that belonged to Arignar Anna Zoological Park, Vandalur, Chennai. Samples were collected from different pheasants such as Indian peafowl (15 samples), White peafowl (21 samples), Pied peafowl (8 samples), Brown peafowl (5 samples), Red jungle fowl (3 samples), Grey jungle fowl (2 samples), Black shoulder (10 samples), Silver pheasant (5 samples), Golden pheasant (1 sample), Ring necked pheasant (1 sample) and Peach peafowl (5 samples). Samples were stored in small containers filled with $10 \%$ formalin. The samples were thoroughly examined for the presence of various endoparasites using centrifugal sedimentation, floatation techniques and direct smear as suggested by Soulsby (1982).

\section{Results and Discussion}

Samples from droppings of captive pheasants birds were subjected to detailed parasitological examinations. Examination revealed the presence of endoparasites such as Ascaridia sp. (21.05\%), Capillaria sp. (34.02\%), Strongyloidessp. (15.78\%), Strongyle (36.84\%), oocyst of Eimeriasp (31.57\%), Acanthocephala sp. (10.52\%), Hymenolepsis sp. (5.26\%) and mixed infections (57.89\%). Details are presented in table 1 . Our results are strong indicative of the need for periodical assessment of droppings for endoparasites which will help in the timely treatment of parasitic infections.

The birds in zoo are often subjected to an additional stress of caged captivity, overcrowding and the environmental conditions which are conducive for the development of parasites. As a result, the birds in captivity generally harbour more parasitic infections as compared to their counterparts living freely. The incidence of helminthic parasites in all birds was observed higher than the zoo animals (carnivores, omnivores and herbivores) by Dhoot et al., (2002).

The prevalence of Ascarids along with other endoparasites observed in our study was in accordance with the report furnished by Greve (1996). Incidence of coccidiosis in such as kite (Milvus migrans) and love bird (Agapornis sp.) was recorded by Jayathangaraj et al., (2008) at Arignar Anna Zoological Park, Vandalur.

Eggs of Hymenolepis sp. was encountered in this study, which was in accordance with the findings made by Fowler (1986) who reported the occurrence of Hymenolepsis sp. In the duodenum of peafowl and in such cases, stable flies acted as intermediate hosts. 
Table.1 Incidence of Endoparasites in Arignar Anna Zoological Park-Vandalur ( $\mathrm{n}=76)$

\begin{tabular}{|c|c|c|c|c|c|c|c|c|}
\hline $\begin{array}{l}\text { Species of } \\
\text { the bird }\end{array}$ & $\begin{array}{l}\text { Ascarid } \\
\text { sp }\end{array}$ & $\begin{array}{c}\text { Eimeria } \\
\text { sp }\end{array}$ & $\begin{array}{l}\text { Strongyles } \\
\text { sp }\end{array}$ & $\begin{array}{c}\text { Strongyloides } \\
\text { sp }\end{array}$ & $\begin{array}{c}\text { Capillarias } \\
\mathbf{p}\end{array}$ & $\begin{array}{c}\text { Acanthoscephalan } \\
\text { sp }\end{array}$ & $\begin{array}{c}\text { Hymenolepsis } \\
\text { sp }\end{array}$ & Mixed \\
\hline $\begin{array}{c}\text { Indian } \\
\text { Peafowl } \\
\mathrm{N}=15\end{array}$ & $3(20)$ & $3(20)$ & $7(46.6)$ & $2(13.3)$ & $5(33.3)$ & $2(13.3)$ & $1(6.66)$ & $9(60)$ \\
\hline $\begin{array}{c}\text { White } \\
\text { Peafowl } \\
\text { N-21 }\end{array}$ & $4(19)$ & $5(23.8)$ & $8(38.09)$ & $8(38.09)$ & $7(33.3)$ & $2(9.52)$ & $2(9.52)$ & $13(61)$ \\
\hline $\begin{array}{c}\text { Pied } \\
\text { Peafowl } \\
\mathrm{N}=8\end{array}$ & $2(25)$ & $3(37.5)$ & $2(25)$ & $1(12.5)$ & $3(37.5)$ & $1(12.5)$ & Nil & $5(62)$ \\
\hline $\begin{array}{c}\text { Brown } \\
\text { peafowl } \\
\mathrm{N}=5\end{array}$ & $1(20)$ & $4(80)$ & Nil & Nil & $2(40)$ & $1(20)$ & Nil & $4(80)$ \\
\hline $\begin{array}{c}\text { Black } \\
\text { shoulder } \\
\mathbf{N}=10\end{array}$ & $2(20)$ & $4(40)$ & $4(40)$ & $1(10)$ & $3(30)$ & $1(10)$ & $1(10)$ & $6(60)$ \\
\hline $\begin{array}{c}\text { Golden } \\
\text { Pheasant } \\
\text { N=1 }\end{array}$ & Nil & Nil & $1(100)$ & Nil & Nil & Nil & Nil & Nil \\
\hline $\begin{array}{c}\text { Silver } \\
\text { Pheasant } \\
\text { N=5 }\end{array}$ & $1(20)$ & $3(60)$ & $3(60)$ & $2(40)$ & $2(40)$ & Nil & Nil & $3(60)$ \\
\hline $\begin{array}{c}\text { Peach } \\
\text { peafowl } \\
\mathrm{N}=\mathbf{5}\end{array}$ & $2(40)$ & Nil & $2(40)$ & $1(20)$ & $2(40)$ & $1(20)$ & NIL & $2(40)$ \\
\hline $\begin{array}{c}\text { Grey } \\
\text { jungle fowl } \\
\mathrm{N}=2\end{array}$ & Nil & Nil & $1(50)$ & $1(50)$ & $1(50)$ & $1(50)$ & Nil & $2(100)$ \\
\hline $\begin{array}{c}\text { Red jungle } \\
\text { fowl } \\
N=3\end{array}$ & $1(33.3)$ & $2(66.6)$ & Nil & Nil & $1(33.3)$ & Nil & Nil & $2(66)$ \\
\hline $\begin{array}{c}\text { Ring neck } \\
\text { pheasant } \\
\text { N-1 }\end{array}$ & Nil & Nil & $1(100)$ & Nil & Nil & Nil & Nil & Nil \\
\hline
\end{tabular}

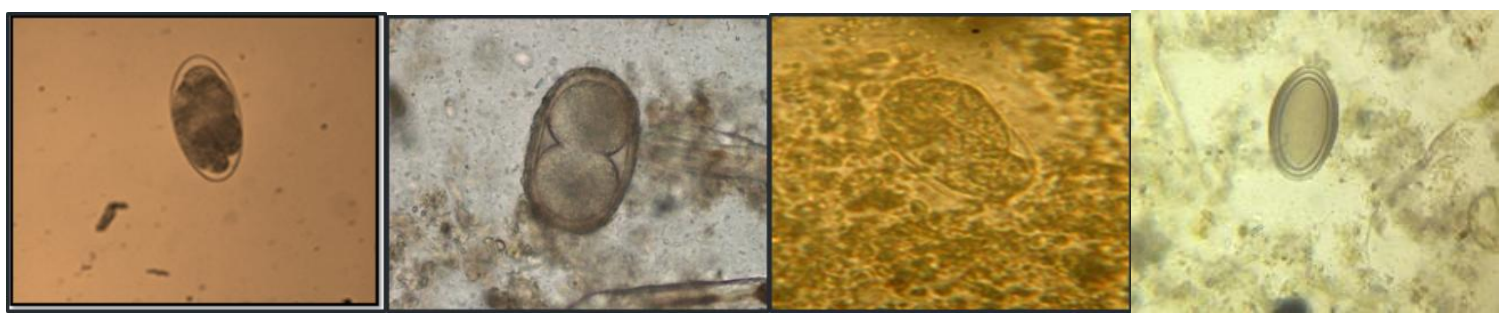

Strongylesp (40X) Ascaridsp (40X) Strongyloidessp (40X) Acanthocephalan sp (40X)
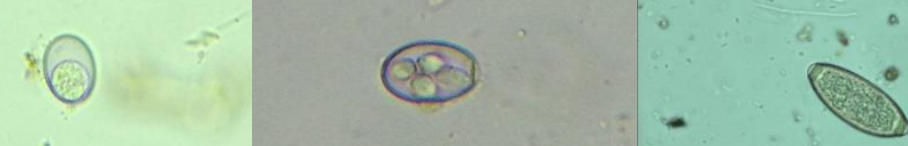

Eimeria Oocysts (40X) Eimeriasporulated Oocyst (40X) Capillariasp (40X) Hymenolepissp (40X) 
The helminthic eggs in faecal samples of several avian species at Lucknow and Delhi zoos were detected by Chauhan et al., (1973), who identified one or more of spiruroid, ascarid and capillarid types. The Indian peafowl (Pavocristatus), Burmese peafowl (P. munticus) and guineafowl (Numida meleagris) were found infected with all three types of infections. Other than these, Strongyloides avium was found in golden pheasant (Chrysolo phuspictus) and in parakeet (Psittacula eupatsia) and hymenolepid in sarus crane (Grus antigone) and common crane (G. grus). All of these parasites were without apparent clinical symptoms.

Prevalence of gastrointestinal parasites in captive birds was reported coprologically by Reddy et al., (1992) at Bannerghatta National Park, Bangalore. The examination revealed the presence of nematodes (31\%), comprising of Ascaridia sp., strongyle and Capillaria sp. in almost equal proportion, followed by the tapeworm Hymenolepis (6.9\%). In birds maintained at the zoos in Gujarat, 48.11 per cent faecal samples were found positive (Patel et al., 2000).

Kashid et al., (2003) reported an incidence of $88.33 \%$ parasitic infections in peacocks, predominantly helminthic in nature in six different locations of Maharashtra. Faecal screening for endoparasites among freeranging peafowl at Tirunelveli and Kanyakumari in Tamil Nadu (Subramanian et al., 2003) revealed the infection with a range of nematodes (Heterakis, Ascaridia, Capillaria, Syngamus, and Strongyloides species), an acanthocephalan and an unidentified cestode egg. Selvarajet al., (2003) recovered acuarid worms from the gizzard and proventriculus, which were identified as Skrjabinocara squamataat necropsy of three cormorants (Phalacrocorax niger) in Chennai (Tamil Nadu). Sahoo et al., (2009) assessed the prevalence of gastrointestinal parasites of captive birds of Nandankanan zoo, Odisha. Forty-four species of birds were screened for presence of gastrointestinal parasitic infection during three seasons. The overall prevalence rate was $29.54 \%$ (39/ 132). The nematode parasites were predominant, where Ascaridia, Capillaria, Strongyle and Strongyloides species were diagnosed in 43.10, 18.97, 6.90 and $3.45 \%$ birds, respectively.

\section{References}

Athar, M., A. Shakoor, G. Muhammad, N.M. Asi, and M.Saqib. 2001. Surgical rectification of thread-associated Glossoptosis in peafowls. Pakistan Vet. J. 21(2):92-94.

Badran, I., and D. Lukesova, 2006. Control of Coccidiosis and Different Coccidia of Chicken in Selected Technologies used in Tropics and Subtropics. Agricultura Tropica Et Subtropica. 39(1):39-42.

Chauhan P.P.S., B.B. Bhatia, G.S. Arora, R.D. Agrawal and S.S Ahluwalia.1973. A preliminary survey of parasitic infections among mammals and birds at Lucknow and Delhi zoos. Indian Journal of Animal Sciences 43: 163168.

Dhoot V.M., S.V Upadhye and S.W. Kolte. 2002. Prevalence of parasitism in wild mammals and birds of Maharajbag zoo, Nagpur. Indian Veterinary Journal 79: 225-227.

El-Shahawy, S. I., 2010. Eimeriapavo aegyptica sp. nov. (Apicomplexa: Eimeriidae) in feces of Indian Peacocks, Pavocristatus Linnaeus, 1758 (Galliformes: Phasianidae) from Egypt. MemInst Oswaldo Cruz, Rio de Janerio105 (8): 965-969.

Flower, M.S.S., 1938. The duration of life in animals - IV. Birds: special notes by orders and families. Proceedings of the Zoological Society of London. Pp. 195235. 
Fowler, M.E., 1986. Zoo and Wild Animal Medicine. Second edn. W.B. Saunders Company, Philadelphia. Pp.471.

Greve, J.H., 1996. Gastrointestinal parasites and Parasites of the skin. In: Diseases of cage and aviary birds. $3^{\text {rd }} \mathrm{Edn} . \mathrm{Ed}$ Rosskopf, W.J and R.W.Woerpel. Lea and Febiger. Baltimore.

Jayathangaraj M.G., S. Gomathinagyam and V. Bhakyalakshmi. 2008. Incidence of coccidiosis in captive wild birds. Tamil Nadu Journal of Veterinary and Animal Sciences 4: 156.

Kashid K.P., G.B. Shrikhande and G.R. Bhojne. 2003. Incidence of gastro intestinal helminthes in captive wild animals at different locations. Zoo's Print Journal 18: 1053-1054.

Reddy J.N.R., M.S. Jagannath, P.E. D'Souza and S. Abdul Rahman, 1992. Prevalence of gastrointestinal parasites in wild mammals and captive birds at Bannerghata National Park, Bangalore, India. Indian Journal of Animal Sciences 62: 1046-1048.

Sahoo N., M. Dehuri, K.M.N. Bharti, P.K. Roy, A. Das and R.K. Samantaray. 2009. Prevalence of endoparasitic infection in birds of Nandankanan Zoo. Journal of Veterinary Parasitology 24: 95-96.

Soulsby, E.J., 1982. Helminths, Arthropods and Protozoa of domestic animals. 7th edn, ELBS, Bareilly Tindall, London.

Subramanian K.S., M.C. John and M. Raman. 2003. Pilot study on parasitic fauna of free-ranging Indian peafowl (Pavocristatus). Zoo's Print Journal 18: 1096-1098.138

\section{How to cite this article:}

Pradeep, R., A. Senthilkumar, A. Sangaran, S. Prathaban and Pradeep, A. 2017. Incidence of Endoparasites in Captive Pheasants in Arignar Anna Zoological Park, Vandalur, Chennai. Int.J.Curr.Microbiol.App.Sci. 6(9): 2517-2521. doi: https://doi.org/10.20546/ijcmas.2017.609.309 